\title{
Nasjonale prøver i norske riks- og regionaviser - en historisk tekstanalyse av redaksjonelle framstillinger av nasjonale
}

\section{prover}

\section{Ole Petter Vestheim^ og Leiv Sem}

Nord universitet, Levanger, Norge

\section{Sammendrag}

Siden nasjonale prøver ble innført i Norge i 2004, har de blitt til dels kraftig debattert i ulike typer medier. Gjennom en historisk tekstanalytisk tilnærming til et utvalg artikler har vi undersøkt hvordan nasjonale prøver er presentert i norske riks- og regionaviser i perioden 2004-2017. Analysen viser en klar utvikling i måten nasjonale prøver er brukt og omtalt i mediene på. Analysen antyder en toveis utveksling mellom medienes framstilling og beslutningstakeres politikkutvikling. Måten de nasjonale prøvene har blitt presentert i mediene på, har trolig påvirket allmennhetens, beslutningstakeres og profesjonens oppfatning av skolens samfunnsmandat og opplevelse av skolens kvalitet og skolenes praksis.

Nøkkelord: Standardiserte tester; nasjonale prøver; nyhetsmedia; tekstanalyse; utdanningspolitikk

Mottatt: November, 2018; Antatt: Mars, 2019; Publisert: Mai, 2019

\begin{abstract}
National Tests in Norwegian National and Regional Newspapers - A Historical Text Analysis of Editorial Representations of National Tests

Since the introduction of national tests of pupils in Norway in 2004, the tests have been widely debated in different types of media. Through a historical text analysis of a selection of newspaper articles, we have investigated how national tests have been presented in Norwegian national and regional newspapers during the period 2004-2017. The analysis suggests a two-way exchange between the presentation in the media and the policy development by decision-makers. The media's way of presenting national tests have probably influenced how the mandate and the quality of the school have been perceived by the general public, decision-makers and within the profession. This analysis demonstrates how school practices have been affected by these processes as well.
\end{abstract}

Keywords: Standardized tests, national tests, news media, text analysis, educational policy

^Korrespondanse: Ole PetterVestheim, Epost: ole.p.vestheim@nord.no

(C) 2019 Ole PetterVestheim og Leiv Sem. This is an Open Access article distributed under the terms of the Creative Commons Attribution 4.0 International License (https://creativecommons.org/licenses/by-nc/4.0/), allowing third parties to copy and redistribute the material in any medium or format and to remix, transform, and build upon the material for any purpose, even commercially, provided the original work is properly cited and states its license.

Citation: Ole Petter Vestheim. "Nasjonale prøver i norske riks- og regionalaviser - en historisk tekstanalyse av redaksjonelle framstillinger av nasjonale prøver." Nordisk tidsskrift for pedagogikk og kritikk, Vol. 5, 2019, pp. 27-45. http://dx.doi. 


\section{Innledning}

I denne artikkelen diskuterer vi hvordan nasjonale prøver er framstilt i norske riks- og regionaviser fra 2004 til 2017. Nasjonale prøver ble første gang innført i det norske utdanningssystemet i 2004. På dette tidspunktet var L97 styrende læreplan, en plan som stemte dårlig med ferdighetene de nasjonale prøvene var rettet mot. Prøvene skulle måle elevenes ferdigheter i norsk, matematikk og engelsk. Senere ble dette endret til å omfatte de grunnleggende ferdighetene lesing, regning og engelsk. Bakgrunnen for innføringen var blant annet anbefalinger fra OECD om at Norge trengte et system for kvalitetsvurdering av skolen. Et sentralt poeng var at skolen og skoleeiere skulle ansvarliggiøres for elevenes og skolens oppnådde resultater (Hopfenbeck, 2014, s. 412). Dette kan anses som et avgiørende skifte i norsk skolepolitikk. Tidligere skulle skolene kvalitetssikre seg selv, mens nå skulle kvaliteten kontrolleres eksternt. Dette er beskrevet som en overgang fra en nasjonal pedagogisk «uskyldstilstand» med vekt på «dannelse» til et regime hvor «læringstrykk» var løsenordet (Sjøberg, 2014, s. 30-33). PISA, som er OECDs viktigste instrument når det gjelder utdanningsspørsmål, er blitt en betydelig utdanningspolitisk aktør også i en norsk kontekst (Hovdenakk, 2014, s. 397). Med dette er selve premissene for utdanningsdiskursen endret. Elstad og Sivesind påpeker at «Kjernen i OECDs rammeverk for utdanning er økonomisk teori anvendt på utdanningspolitiske spørsmål» (2010, s. 28). Det var i utgangspunktet bred politisk enighet om at prøvene skulle innføres, men likevel foregikk ikke dette uten debatt om prøvenes intensjon og funksjon. Sentrale spørsmål dreide seg for eksempel om hvorvidt prøvene skulle ha summative eller formative hensikter, eller hvorvidt prøveresultatene skulle gjøres offentlig tilgjengelige eller ikke. Særlig det siste spørsmålet var og er en het potet i debatten om nasjonale prøver. I Dagsavisen 11.7.2017 tok kunnskapsminister Torbjørn Røe Isaksen et tilbakeblikk på spørsmålet om offentliggjøring av resultatene på nasjonale prøver i skolen: "At Ap ikke lenger vil motarbeide praksisen med offentliggiøring av resultatene, viser at det var unødvendig å holde resultatene unna offentligheten $i$ åtte år.» I tillegg kan vi lese følgende uttalelse: «De dystre spådommene til venstresiden er gjort til skamme [...] Åpenhet om resultatene på skolenivå ville føre til rangering, uthenging og mesterskapstenking, ble det påstått. Men denne påstanden holder ikke mål.» Kunnskapsminister Isaksen støttet seg til en undersøkelse som Utdanningsdirektoratet skal ha giennomført av mediedekningen av nasjonale prøver i tidsrommet 2014-2016, hvor det framgikk at de fleste oppslagene var «nøytrale» eller «positive", og at diskusjonen om ordningen ble mindre. Det framgår ikke av artikkelen hvilken spesifikk undersøkelse han viser til. Kunnskapsministeren påpeker her rollen nyhetsmediene kan ha i utformingen av politikk, og ikke minst skolens praksis.

\section{Bakgrunn}

Gjennom mediene får allmennheten innsikt i og kunnskap om samfunnet, og i mediene blir de fleste meninger skapt gjennom diskusjoner, meningsbrytninger og 
forhandlinger. Siden de kun kan tilby et redigert utsnitt av saksforholdene, representerer mediene og journalistikken en sosial konstruksjon av virkeligheten (se Altheide, 2004; Fladmoe, 2013, s. 100). Mediene spiller en nøkkelrolle i politiske sammenhenger gjennom redaksjonelle valg av hvilke saker og fortellinger som skal formidles, og hvordan sakene blir dekket (Fairclough, 2003). Mediedekningen speiler og påvirker meningsdannelse og politiske stemninger på samme tid. Mediene kan være et korrektiv til politikere og byråkratiet, men kan også brukes som et verktøy av disse i utformingen av politikk (Lingard \& Rawolle, 2004, s. 362). Forskningen viser til ulike grader av hvordan mediene virker inn på politiske prosesser, men det er på det rene at mediene er avgiørende for hvordan saker blir forstått, $\mathrm{og}$ at medienes framstillinger reflekterer bredere kulturelle, historiske og institusjonelle sammenhenger (Saraisky, 2016, s. 28). Internasjonalt foreligger det flere studier med dels ulike tilnærminger til hvordan standardiserte prøver framstilles i media. Noen av disse studiene retter søkelyset mot hvordan internasjonale storskalaundersøkelser som PISA presenteres i mediene i de respektive landene der undersøkelsene er foretatt (Baroutsis \& Lingard, 2017; Stack, 2006; Waldow, Takayama \& Sung, 2014). Andre studier kaster lys over hvordan nasjonale standardiserte prøver framstilles i media (Mockler, 2013), eller hvilken rolle media påtar seg mer eller mindre bevisst i spillet om utforming av utdanningsreformer (Blackmore \& Thorpe, 2003; Lingard \& Rawolle, 2004). Mediene spiller en betydningsfull rolle i framstillingen og forståelsen av standardiserte prøver. Samtidig er det viktig å påpeke at det er til dels store forskjeller mellom land og deres respektive utdanningspolitiske styringsformer. I noen land er resultatene fra slike standardiserte prøver brukt som basis for ulike former for reaksjoner og for endringer av praksis. Eksempler kan være sanksjoner og forflytting av lærere, oppsigelse av rektorer som ikke oppnår gode nok eller forbedrede resultater, og stenging av skoler som giør det dårlig over tid (Hargreaves \& Shirley, 2009). Under slike forhold, ofte kalt «high-stake testing regimes», vil det stå mye på spill for de involverte partene. Det er derfor ikke overraskende at forskning på utdanningssystemer som er underlagt slike styringsregimer, tegner et bilde av skoler som vektlegger testene på bekostning av andre aktiviteter og formål, og som maksimerer ressursbruken inn mot det som kan testes og måles. Aktiviteter som bygger sosial kompetanse, fysisk aktivitet eller ikke har direkte betydning for testresultatene, blir lidende siden de ikke er sett som nyttige i sammenheng med prøvene som skal giennomføres (Berliner, 2011). I Norge har ikke de nasjonale prøvene offisielt tilsvarende funksjon eller formål. Hopfenbeck (2014, s. 412) peker på at ingen slike tilfeller har blitt dokumentert i Norge. En studie av Elstad (2009) viser derimot at mediene spiller en sentral rolle i framstillingen av resultater fra de nasjonale prøvene, ved å presentere hvilke skoler som har fătt gode resultater, og hvilke som har fått dårlige. Studien viser at skoler som har erfart negative oppslag i media endrer sin praksis, og vektlegger undervisning i emner som måles på disse prøvene, slik at lignende ubehag unngås. Media kan dermed forstås som en mer eller mindre frivillig pådriver for praksisendringer i skolen. 
For øvrig er det begrenset med forskningslitteratur som kaster lys over mediedekningen av nasjonale prøver i Norge. Spesielt er det lite om hvordan mediedekningen kan påvirke allmennhetens, beslutningstakeres og profesjonens oppfatning av skolens samfunnsmandat og opplevelse av skolens kvalitet. Med dette som bakteppe ønsker vi å belyse følgende forskningsspørsmål: Hvordan er nasjonale prøver framstilt redaksjonelt i norske riks- og regionsaviser fra 2004 til 2017? Vi ønsker å se om det har skjedd en utvikling i måten nasjonale prøver omtales på og brukes i mediene. Denne mediedekningen er dels en avspeiling av en politisk utvikling, ønsket eller uønsket. Dels er mediedekningen i seg selv en drivende kraft i utformingen av politikk. Begge disse perspektivene vil være viktige å ta med seg i undersøkelsen. Med denne historiske redegjørelsen ønsker vi å danne en bakgrunn for refleksjon over hvordan praksis påvirkes.

I analysene våre har vi valgt ut tekster og ytringer fra nyhetsmediene, med utgangspunkt $i$ at nyhetsdekningen er en sentral drivkraft bak politiske prosesser - og motsatt at politiske prosesser avspeiles i mediebildet. Oppmerksomhet i mediene kan bringe en gitt sak til ministerens bord eller, på et lokalt nivå, til rektorens dagsplan. Men mediedekningen er også en viktig kilde til informasjon for offentligheten, for dialogen mellom borgere og styresmakter og lovgivere. I noen tilfeller er medienes reportasjer de eneste kildene vi har til visse aktørers synspunkter. Selv med alle sine begrensninger i tabloidformat, i journalisters tidsnød og deres ofte mangelfulle innsikt, er medienes fortellinger viktige for hvordan de nasjonale prøvene blir forstått, og for hvordan resultatene blir brukt.

\section{Metodisk framgangsmåte}

For å analysere medienes framstilling av de nasjonale prøvene har vi av praktiske årsaker begrenset oss til de skriftlige mediene. Etermedienes dekning faller utenfor vår undersøkelse. Vi anerkjenner at viktige deler av debatten og informasjonsdelingen foregår i etermedienes flater og kanaler, men vi valgte likevel bort disse, da skrevne tekster gir et mer analytisk håndterbart materiale. Vi har i dette antatt at en gjennomgang av strategisk valgte aviser vil gi oss en tilstrekkelig bred inngang til å forstå den generelle utviklingen. Det er klart at dette utvalget vil kunne usynliggjøre visse aktører, synspunkter og uttrykksmåter som kanskje lettere vil søke til etermediene enn skriftmedienes spalter. For vår undersøkelse, som i hovedsak retter seg mot samspillet mellom mediene og politikkutforming, mener vi likevel at papirmediene gir et tilstrekkelig bredt bilde.

Videre har vi valgt å ta for oss et utvalg av avisene for å begrense materialet til en håndterlig mengde. Vi har lagt vekt på å finne aviser med stort gjennomslag blant sine lesere, både forstått som det allmenne publikum og beslutningstakerne - noe som et stykke på vei faller sammen. Basert på tall fra Mediebedriftenes Landsforening valgte vi ut de ni dagsavisene med høyest antall lesere (2018). Dette gav oss en fordeling 
av aviser med nasjonalt nedslagsfelt (Aftenposten, Dagbladet, Verdens Gang og Klassekampen), men også aviser som kunne representere de ulike regionene (Adresseavisen, Bergens Tidende, Stavanger Aftenblad, Dagsavisen). Den nordligste landsdelen var ikke representert blant avisene med størst lesertall. Vi valgte derfor å supplere vårt utvalg med avisa Nordlys.

Dette utvalget av aviser peker på en sentrum-periferi-dimensjon som må sies å være et allment trekk i norsk medievirkelighet. De mest folkerike regionene slår gjennom i utvalget vårt, særlig avisene som kommer ut i hovedstaden. Den lokale forankringen kommer til syne ikke bare $\mathrm{i}$ aviser som retter seg mot et regionalt publikum, som Dagsavisen. Også aviser som har et nasjonalt nedslagsfelt, som Dagbladet og $V G$, står i et spenn mellom å fungere som nasjonale og som lokale institusjoner. Denne sentrum-periferi-dimensjonen finner vi igjen i gjennomgangen av vårt materiale: Situasjonen i Osloskolen og debatten rundt denne spiller en rolle også ut over det regionale/lokale planet. Dette gjelder også i saker der de spesifikke spørsmålene som debatteres, er særegne for Osloskolen og avgrenset av de lokale styringsforholdene. En del av dette fokuset kan trolig forklares ganske enkelt med at det er til disse skolene mange av journalistene og redaktørene sender sine egne barn. Viktigere er kanskje det fokuset som naturlig følger med hovedstadsstatusen og folketallet. Som vi senere vil vise, har i tillegg skolepolitikken i Oslo vært ført på tvers av nasjonale føringer. I alle tilfeller ser vi ikke dette Oslo-fokuset som en svakhet ved utvalget vårt. Tvert imot er dette trekket ved medienes tilhørighet viktig for å forstå dynamikken mellom medier og politikkutformingen. I utvalget av regionale aviser merker man seg en dominans av Schibsted-aviser. Disse avisene har lange tradisjoner og legger stor vekt på utdanningsrelatert stoff. Samtidig har disse avisene en samkjøringspolicy på tvers av regionene, og de deler dessuten et visst verdigrunnlag. I en viss forstand har dermed ønsket om å hente inn bredde regionalt samtidig brakt med seg en innsnevring på det overregionale nivået. Et bredere bilde kunne fås ved å supplere med konkurrerende aviser. Vi har valgt ikke å gjøre dette, fordi utvalget da ville bli mer vilkårlig, og hensynet til gjennomslag blant publikum da ville kunne bli mindre tydelig. Utvalget som helhet vil derimot dekke et spenn av politiske forankringer.

For å hente inn det empiriske materiale har vi brukt søketjenesten som er innebygd i Retrievers mediearkiv Atekst. Dette er et mediearkiv som er eid og administrert av blant andre nyhetsbyrået Norsk Telegrambyrå. Dette arkivet inneholder skanninger av papirutgavene av både nasjonale og regionale aviser, dog ikke avisen Dagens Naringsliv som ellers ville være en naturlig kilde. Vi har søkt etter artikler i både riksog regionsaviser i tidsrommet mellom 1.1.2004 og 31.12.2017.Vi brukte søkeordene «nasjonale prøver» og resultat ${ }^{\star}$ og skole ${ }^{\star}$, og hentet ut de artiklene fra våre utvalgte aviser som inneholdt alle disse søkeordene. Den totale mengden av artikler var 2061 da søket ble gjennomført. Vi presenterer antall treff per år og totalt, fordelt på aviskildene i tabellen som følger under. 
Tabell 1. Totalt antall treff fordelt etter avis og år.

\begin{tabular}{lrrrrrrrrrrrrrrr}
\hline Kilde & 2004 & 2005 & 2006 & $\mathbf{2 0 0 7}$ & $\mathbf{2 0 0 8}$ & $\mathbf{2 0 0 9}$ & $\mathbf{2 0 1 0}$ & $\mathbf{2 0 1 1}$ & $\mathbf{2 0 1 2}$ & $\mathbf{2 0 1 3}$ & $\mathbf{2 0 1 4}$ & $\mathbf{2 0 1 5}$ & $\mathbf{2 0 1 6}$ & $\mathbf{2 0 1 7}$ & Totalt \\
\hline Adresseavisen & 21 & 46 & 6 & 7 & 22 & 15 & 15 & 11 & 19 & 17 & 8 & 13 & 7 & 9 & 490 \\
Aftenposten & 30 & 70 & 14 & 19 & 36 & 42 & 45 & 61 & 20 & 48 & 27 & 42 & 16 & 20 & 266 \\
Bergens Tidende & 21 & 54 & 6 & 21 & 21 & 19 & 11 & 12 & 11 & 16 & 11 & 13 & 6 & 11 & 233 \\
Dagbladet & 14 & 16 & 17 & 9 & 22 & 8 & 13 & 30 & 10 & 4 & 13 & 18 & 6 & 3 & 223 \\
Dagsavisen & 11 & 29 & 7 & 6 & 12 & 18 & 21 & 22 & 8 & 11 & 27 & 44 & 18 & 32 & 216 \\
Klassekampen & 5 & 16 & 3 & 10 & 10 & 16 & 8 & 19 & 5 & 21 & 16 & 21 & 9 & 17 & 183 \\
Nordlys & 4 & 27 & 4 & 1 & 10 & 7 & 9 & 18 & 18 & 5 & 8 & 11 & 8 & 11 & 176 \\
Stavanger Aftenblad & 13 & 47 & 4 & 11 & 25 & 11 & 21 & 15 & 19 & 18 & 12 & 7 & 6 & 14 & 141 \\
VG & 3 & 21 & 1 & 5 & 13 & 6 & 6 & 7 & 7 & 25 & 1 & 27 & 6 & 5 & 133 \\
\hline Totalt & 122 & 326 & 62 & 89 & 171 & 142 & 149 & 195 & 117 & 165 & 123 & 196 & 82 & 122 & 2061 \\
\hline
\end{tabular}

De ulike avisene har et bredt register av ulike sjangre, hver med sine begrensninger og styrker. Vi har valgt å fokusere på det redaksjonelle stoffet i vår gjennomgang. I denne sammenhengen betyr det nyhetsoppslag og kommentarstoff $i$ avisenes lederartikler. Innsendte leserbrev og signerte kronikker som ikke står for avisens regning, har vi ikke tatt med i materialet. Årsaken til denne vektleggingen er dels av praktisk art. Å inkludere kommentar- og meningsstoff kunne gitt analysen større bredde, men stoffmengden ville blitt mindre håndterbar. Vi har her ikke ambisjoner om å få det totale bildet av avisenes tematisering av nasjonale prøver. Vårt primære ærend er å søke mønstre i redaksjonenes oppfatninger av nasjonale prøver. Disse mønstrene danner videre grunnlag for refleksjoner og diskusjon om beslutningstakeres utforming av politikk.

I framstillingen som følger under, har vi lagt vekt på å få fram overordnede og generelle trender i medienes behandling av de nasjonale prøvene. Ut fra dette har vi skrevet ut en periodisert framstilling av omtalen av de nasjonale prøvene og skolens praksis, og søkt å identifisere og framheve de sentrale trekkene i utviklingen. Vi kan karakterisere dette som en induktiv forskningsstrategi, hvor kategoriene er et resultat av analysen. Framstillingen er dermed resultat av et fortolkingsarbeid, og det ligger $\mathrm{i}$ valget av metode at tekster og oppslag som er avvikende fra det generelle bildet, kan falle ut av framstillingen. De tekstene som vi viser direkte til i analysen, er lagt til i et appendiks, der publiseringssted og -tid og full tittel framgår.

\section{Historisk gjennomgang av mediedekningen}

\section{Implementeringsfasen 2004-2006}

I 2004, året da nasjonale prøver ble innført, var medieinteressen liten. I den grad mediene avspeilet en debatt, dreide denne seg i stor grad om testene skulle innføres eller ikke. Trolig hadde dette å gjøre med at det var relativt bred politisk enighet om 
innføringen av testene; noe måtte gjøres for å kontrollere og heve skolekvaliteten. Et sentralt poeng som likevel ble tatt opp til drøfting i mediedekningen, var hvilke ferdigheter som skulle testes. I tillegg ble det også løftet fram noen poenger som skulle vise seg å bli viktigere i debatten i tiden som fulgte. Utdanningsministeren fra Høyre, Kristin Clemet, tok sterkt til orde mot rangering av vinner- og taperskoler, «en form for journalistikk som utdannelsesministeren signaliserer at hun misliker sterkt. Offentliggjøring av de nasjonale prøvene vil derfor bli gjort på en måte som ikke legger til rette for rangering på landsbasis» (Aftenposten, 17.6.2004). På samme tid ble det stilt spørsmål ved hvordan testene vil endre hverdagen til lærerne, og om skolens praksis og forståelse av læring ville innsnevres (for eksempel Bergens Tidende, 30.3.2004). Disse spørsmålene skulle senere vise seg å være berettiget.

Det følgende året så vien tydelig økt oppmerksomhet i media. Antallet artikler i utvalget vårt gikk fra 122 i 2004 til 326 i 2005. Dette kan ses i sammenheng med at den politiske diskusjonen spisset seg til. Debatten handlet dels om økonomiske og praktiske sider: Lærere tok til orde mot at de ble pålagt økt arbeidsmengde uten at de fikk kompensasjon for dette, og kommunene som skoleeiere hevdet de ikke hadde etterspurt prøvene, og derfor ikke burde ta kostnaden. Samtidig ble det uttrykt en sterk skepsis fra rektorer, lærere, elever, foreldre og skoleeiere. Eksempler på slike artikler er "Lærer-nei til offentliggiøring»(Dagsavisen, 25.8.2005), «Vil ikke rette nasjonale prøver» (Aftenposten, 11.5.2005), "Foreldreaksjon mot nasjonale prøver» (Dagsavisen, 3.4.2005) og «Boikottet nasjonale prøver: Elevrådsmedlem truet med utkastelse» (Stavanger Aftenblad, 31.1.2005). Skepsisen var basert på testenes kvalitet, intensjonen med testene og at testene ikke bidro med kunnskap om elevene som lærerne ikke hadde fra før. En oppfatning som gikk igjen i artiklene, var at prøvene verken gienspeilte pensum eller læreplan, og at de ikke fungerte formativt da studentene ikke fikk tilbakemelding på besvarelsene sine. Det er interessant å legge merke til at et poeng som senere skulle stå sentralt i kritikken, kommer til syne for første gang i utvalget vårt allerede i januar 2005: I en $V G$-artikkel pekes det på drilling av elevene i forkant av prøvene, og både representanter fra lærerne og elevorganisasjonene tar til orde mot utviklingen ( $V G, 18.1 .2005)$.

Etter mye kritikk av prøvenes kvalitet og legitimitet ble 2006 et pauseår. Etter regjeringsskiftet ble det vedtatt ikke å avholde nasjonale prøver dette året. Systemet skulle evalueres og prøvene eventuelt forbedres før de atter skulle tas i bruk i skolen. Daværende kunnskapsminister fra Sosialistisk Venstreparti, Øystein Djupedal, ville gieninnføre nasjonale prøver, men endre dem i retning av formative heller enn summative hensikter, som et verktøy for læring heller enn en test på skolens kvalitet. Prøvene skulle ikke lenger anses som fagprøve i matematikk eller norsk, men i stedet være utformet i den hensikt å kartlegge elevenes måloppnåelse i de grunnleggende ferdighetene regning og lesing samt engelsk. Djupedal ønsket også å stenge det Dagsavisen omtaler som den foregående kunnskapsminister Kristin Clemets "prestisjeprosjekt», skoleporten.no (Dagsavisen, 28.3.2006). I denne portalen skulle resultater på skolenivå publiseres åpent for allmennheten, men uten at skolene ble gjenstand for 
rangering. Resultatene skulle etter gjeninnføringen kun gjøres tilgjengelig for de det angikk: skoleeier, lærere, elever og foreldre. Prøvene skulle legges til høsten i stedet for våren for å understreke prøvenes formative hensikt. Dette ble positivt mottatt av lærere og elevorganisasjoner som opplevde å bli tatt med på råd underveis. I Oslo erklærte derimot skolebyråden Torger Ødegaard (H) en «Djupedal-fri sone» og innførte det som omtales av Aftenposten som «tidenes hardeste prøveregime». Skolebyråd Ødegaard erklærer: «-Vi skal gi flere prøver enn norsk skole noensinne har opplevd. Ikke for prøvenes egen skyld, men fordi det er den beste - den eneste! - metoden for å skaffe sikker kunnskap om at elevene faktisk lærer det de skal» (Aftenposten, 23.4.2006). Ødegaard «fnyser av argumentet om at prøvene vil stjele mye tid fra skolehverdagen. - Dette er selve skolehverdagen, ikke noe som kommer i tillegg. Dette er skolens kjernevirksomhet; det handler om å være informert om hva elevene lærer, slår han fast» (Aftenposten, 23.4.2006). Oslo skiller dermed lag med resten av skole-Norge og den nasjonale skolepolitikken. Denne uttalelsen fra skolebyråden kan man se som et uttrykk for en fordreining og en innsnevring av skolens samfunnsmandat, der opplæringen tradisjonelt er forstått som mye mer kompleks og bredere sammensatt (jf. Hovdenakk, 2014; Sjøberg, 2014). Samtidig er dette et frampek mot noe som skulle bli tydeligere i de kommende årene.

\section{Reform og rangering 2007-2010}

Etter boikott og misnøye med de tidligere prøvene er tonen i 2007 en annen. Etter pausen kommer de nasjonale prøvene tilbake, men endret $\mathrm{i}$ form og funksjon: «-Tidligere sa barn at de gruet seg til prøvene fordi de følte at det var skolen deres som ble testet på om den var bra nok, forklarer Djupedal. - Nå skal prøvene bli et verktøy for læring i stedet, sier han.» (Dagsavisen, 28.8.2007) Utdanningsdirektoratet gjorde det klart at resultatene fra prøvene skulle tjene som en tilbakemelding til elevene, og at det ikke skulle legges til rette for offentliggiøring og rangering. Mens resultatene tidligere ble offentliggiort for den enkelte skole, var det nå kun resultatene på fylkesog kommunenivå som skulle være tilgjengelige (Adresseavisen, 1.9.2007). Trass i dette så rangeringen av skoler sin spede begynnelse i enkelte aviser. Det oppsto en gryende interesse for hvem som var best, og hvem som var dårligst, i avisene. Eksempler på slike artikler er: «Slik ble Smeaheia testvinner» (Stavanger Aftenblad, 20.12.2007) og "Bergenshåpet Hop» (Bergens Tidende, 7.12.2007). Med dette begynte skolen som konkurransearena for resultater å synliggjøres i mediebildet. Det som mange advarte mot, var nå tydelig i emning. Det kommer klart fram at der skoleeiere valgte å offentliggiøre resultatene på prøvene, grep mediene muligheten til å rangere skolene og lage overskrifter. Om det var skoleeiere som i noen tilfeller tilskyndet offentliggjøring, eller om mediene søkte innsyn og publiserte rangeringer uten skolenes medvirkning, har vi ikke kunnet avgjøre basert på vårt kildemateriale. Uansett kan året 2007 oppfattes som et brudd, og en ny begynnelse.

Presentasjonen av vinneren og taperen ble typisk fulgt av intervjuer og forklaringer. I Adresseavisen ble følgende overskrift presentert: «Elevene i sør scorer bedre enn 
de i nord». Her henviser saken til at nordtrønderske elever presterte dårligere enn elever i Sør-Trøndelag både på lesing, regning og engelsk. Kommunene Selbu og Meldal i Sør-Trøndelag ble trukket fram og karakterisert som de dårligste kommunene (Adresseavisen, 5.12.2007). Mange aviser presenterte tallrike artikler med fokus på resultater, hvilke kommuner som var best, og hva som kjennetegnet disse. Overskriftene og avisreportasjene presenterte ulike forklaringer på hva som bidro til suksess på prøvene. Det ble skrevet om sosial bakgrunn, kartlegging, åpenhet, lærevilje, osv. (Aftenposten, 12.11 og 13.11.2008; Stavanger Aftenblad, 13.11.2008). Ett kjennetegn som ofte ble framhevet av byråkrater, skoleledere og lærere, og som ble utviklet til en årsaksforklaring, var størrelsen på kommunen. Små kommuner med en populasjon på mindre enn 50000 mennesker ble for eksempel presentert som dårligere enn større kommuner. Til dette sier direktør i Utdanningsdirektoratet Petter Skarheim i et intervju med Aftenposten at: «Skole er den viktigste kommunale tjenesten. Klarer ikke kommunene å levere denne, bør de kanskje tenke på å slå seg sammen eller gå inn i tettere samarbeid med nabokommunene» (Aftenposten, 4.6.2008). Resultatene blir dermed brukt i et politisk verdispørsmål der den instrumentelle rasjonaliteten er tydelig og førende.

I 2008 var det fortsatt fokus på offentliggiøring eller ikke. I Stavanger Aftenblad forklarte for eksempel skolerådgiver i Stavanger kommune Rune Knutsen at kommunen hadde valgt å samle skolenes resultater på en åpen portal. Han erkjente at det kunne være en fare med publiseringen, "for eksempel [at] mediene gir enkeltresultater stor oppmerksomhet og ukritisk rangerer skolene i best og dårligst på dette grunnlaget. For å unngå sensasjonslyst, legger vi dermed ut resultatene fra mange undersøkelser» (9.4.2008). Altså forsøkte man i forkant å bøte på en skade som trolig ville oppstå.

I kjølvannet av diskusjonene om hva som fremmer eller hemmer gode resultater på de nasjonale prøvene, ble det også viet plass i enkelte aviser til kritikk av systemet. I Dagsavisen (14.11.2008) hevdet lederen i Utdanningsforbundet, Helga Hjetland, at skoleprøver innbyr til juks og snarveier, og at prøvene ble misbrukt av skoleledere som ville smykke seg med gode resultater. Reportasjen rettet dermed søkelyset mot hvilke praksiser som kunne ligge bak skolenes resultater.

I 2009 er det få saker om nasjonale prøver i avisene (se tabell over). Dette kan ses i sammenheng med at systemet med de nasjonale prøvene på dette tidspunktet hadde begynt å sette seg. I 2010 hadde de blitt en del av dagens orden, og de ble i større grad tatt for gitt i avisenes dekninger og i debattenes spørsmålsstillinger. De ble for eksempel lagt til grunn av utdanningsdirektør Petter Skarheim som i Dagsavisen (9.2.2010) mante til opprør mot dårlige skoler. Spesielt var det de små kommunene som igjen fikk kritikk for ikke å levere gode nok resultater, og for at de framsto som B-skoler sammenlignet med skoler i større kommuner. «Dårlige resultater på nasjonale prøver burde føre til et folkeopprør på lik linje med at det avdekkes dårlig vannkvalitet i kommunen", sa han. Senere fortsatte Skarheim med det politiske budskapet om å danne større skoler. «Store skoler har mange lærere, og da er det også samlet mye kunnskap 
på skolene», forklarer han det med (Dagbladet, 24.6.2010). Avisene fortsatte å presentere tabeller med de beste og dårligste skolene, med tilhørende forklaringer på deres suksess eller eventuelt fiasko. I ettertid virker det som om mediedekningen gjennom rangeringen har skapt en kommunal kløft heller enn et nasjonalt løft.

\section{Et hardere klima 2011-2014}

Året 2011 særpreges av at klimaet hardner til, tilsynelatende både i skolen og i debatten om den. I Aftenposten gikk professor i pedagogikk Thomas Nordahl ut og hevdet at økningen av elever med spesialundervisning skyldes et fokus på prestasjoner, og press på elevene som fungerer dårlig: «Vi mener blant annet nasjonale prøver og Pisa-resultater fører til økt prestasjonspress. Dette kan igjen føre til at de som presterer dårlig føler at de trenger mer hjelp", uttalte han (Aftenposten, 25.1.2011). Som tabellen over viser, fikk man i dette tidsrommet en stor økning i antall artikler, det klart høyeste siden 2005. De mange artiklene tegnet et bilde av et skole-Norge med store forskjeller, ikke minst i Oslo. I Dagsavisen 28.3.2011 ble det slått alarm om Oslo-skolen - selv om elevene skåret høyere enn resten av landet, var det ifølge avisen «et enormt gap» mellom de sterkeste og de svakeste skolene. Avisen intervjuet professor Peder Haug, som uttalte: «- Disse skolene kan bli taperfabrikker, i den forstand at mange av dem som ligger på nivå én leser så dårlig at de kommer til å få store problemer med å fullføre skolegang, ta utdanning eller gjøre karriere.» Til dette innhentet artikkelen respons fra en av skolene som kom dårlig ut. Rektor vedkjente seg ikke betegnelsen taperfabrikk, «men det er klart at dersom elever ikke lykkes med grunnleggende ferdigheter i femte klasse, så kommer de til å slite med å fullføre ungdomsskolen og videregående. 96 prosent av elevene på Gran er minoritetsspråklige» (Dagsavisen, 28.3.2011). I samme avis kritiserte Arbeiderpartiets Tone Tellevik Dahl dagen etter rektorene i hovedstaden for en voksende ukultur: «de prioriterer å heise elever som er midt på treet [...] De gir opp de svakeste.» Den harde anklagen ble utdypet med at motivet var behovet for å gjøre det godt på de nasjonale prøvene (Dagsavisen, 29.3.2011). Skolebyråd fra Høyre, Torger Ødegaard, avviste dagen etter anklagen som "surrealistisk» og "absurd», og tok avstand fra begrepet "taperfabrikker»: «Jeg synes ikke noe om å klistre en sånn merkelapp i panna på rektorer og elever», sa Ødegaard (Dagsavisen, 30.3.2011).

Det hardere klimaet er også synlig i språket og i tiltakene som skulle løse problemene: I VG 4.5.2011 erklærte Høyre-politikere at man ville «tvangsinnføre en tøffere skole» med blant annet flere tester, hardere trykk på basisfag og muntlige karakterer fra 7. trinn. Et offensivt Høyre gikk til angrep på skolepolitikken under den rødgrønne flertallsregjeringen. Høyre-leder Erna Solberg ville ifølge avisen «pålegge sine ordførere å spisse skolepolitikken å gjøre opprør mot den rødgrønne flertallsregjeringens skole. - Innenfor gjeldende lovverk et det fullt mulig for kommunene å gjøre mye selv. Ordførerne våre må presse grensene maksimalt og søke om forsøk og unntak fra loven» ( $V G, 4.5 .2011)$. Det avisen beskriver er en skole hvor den nasjonale politikken skulle utfordres og uthules stykke for stykke. Ordbruken er radikal og 
brutal: «Ingen elever må få fred i Høyres kommuner, før de har lært seg å lese, skrive og regne, sier Elisabeth Aspaker, partiets fremste skolepolitiker» (VG, 4.5.2011). Det var særlig Oslo som fungerte som forbilde eller utprøvingsarena. Kombinasjonen av hovedstadsstatusen og medienes særlige interesse for Oslo-området gjorde at utviklingen her nødvendigvis ville få følger for resten av landet. Testregimet skulle bygges ut, og det skulle bli større åpenhet om resultatene. Unge Høyre foreslo å innføre fem ganger så mange nasjonale prøver (Aftenposten, 5.5.2011). De harde tiltakene møtte reaksjoner. Dagsavisen og Klassekampen rapporterte den 24.5.2011 om "Læreropprør mot prøvepress", og Lektorlaget etterlyste ytringsfrihet i skolen etter at en undersøkelse de hadde fått utført, viste at lærere ikke torde uttale seg offentlig (Aftenposten, 26.5.2011).

Nasjonale prøver kom på nytt i fokus gjennom en debatt om ei bok utgitt av Magnus Marsdal om Oslo-skolen: Kunnskapsbleffen (Marsdal, 2011). Her ble det vist til at tallet på elever henvist til pedagogisk-psykologisk utredning ble doblet på fire år fram til 2010/11, og bruken av spesialundervisning økte kraftig (se f.eks. Dagbladet, 23.8.2011). Marsdal hevdet også at svake elever ble unntatt fra de nasjonale prøvene for ikke å ødelegge skolens resultater. Andre måter å jukse på skal ha vært å ta prøven på nytt, eller å jukse med tiden elevene fikk til rådighet. Andre kritikkverdige forhold han trakk fram, var at elever ikke fikk nødvendig spesialundervisning, fordi ressursene i stedet ble brukt på å bedre prestasjonene til elever som kunne gi skolen bedre skår på de nasjonale prøvene. Marsdals bok ble heftig diskutert i mediene (se f.eks. Aftenposten, 21.12.2011; Dagbladet, 23.8.2011). Mange av påstandene som ble løftet fram $\mathrm{i}$ boka, ble undersøkt og drøftet i tidene som fulgte.

I begynnelsen av 2012 offentliggjorde Utdanningsforbundet en undersøkelse der rektorer ifølge overskriften i Dagbladet "slakter de nasjonale prøvene» (6.12.2012). Mange av rektorene mente kommunene brukte prøvene til å sammenligne og rangere skolene, og at man ikke brukte dem til å iverksette støttetiltak der mangler ble avdekket (Dagbladet, 6.2.2012). Få dager etter fulgte utdanningsminister Kristin Halvorsen fra Sosialistisk Venstreparti dette opp i Aftenposten, og uttalte at hun ville endre de nasjonale prøvene. Særlig ville hun adressere rangerings- og konkurranseaspektet (Aftenposten, 10.2.2012). Ut over i 2012 ble debatten om de nasjonale prøvene dominert av andre spørsmål. I juni offentliggjorde Trondheim Høyre skoleresultatene i kommunen på en egen nettportal. Kommunalråden fra Høyre, Yngve Brox, uttalte i den forbindelse: «Vår plan er å gjøre dette hvert år, helt til vi får makten selv og kan be kommunen om å giøre det [...] Det er på høy tid å få fokus på elevenes læringsutbytte" (Adresseavisen, 22.6.2012). Utdanningsforbundet advarte i samme avis mot offentliggjøring. Dette mente de ville føre til økt fokus på resultatene, og at det ville bli knyttet prestisje til å gjøre det best mulig (Adresseavisen, 22.6.2012). Disse reaksjonene ble i sin tur avvist i en lederartikkel i Adresseavisen med formuleringer som "forutsigbar motstand", "programmatisk» bekymring, og at "skoleforskjeller usynliggjøres», og "Kartleggingsprøver og nasjonale prøver i lesing, regning og engelsk er den aksepterte måten læringsutbyttet i skolen måles på i dag» (26.6.2012). 
Lederartikkelen peker mot viktige utviklingstrekk i diskursen om nasjonale prøver. Både gjennom innholdet $\mathrm{i}$ de bastante påstandene og $\mathrm{i}$ de tungt ladede vendingene er lederartikkelen et tegn på at det er en glidning i forståelsen og verdsettingen, og i bruken av de nasjonale prøvene.

Ut over i 2013 ble tegn på visse uheldige følger av systemet tydeligere. En analyse førsteamanuensis i pedagogikk Christian Beck hadde foretatt for $V G$, viste at svake elever ble fritatt fra testene. Dette syntes å dokumentere en beskyldning som Oslo-skolene lenge hadde levd med: at resultatene blir bedre på skolene som fritar mange. Funnene viste at svake elever ble holdt borte for å blåse opp resultatene. Avisen skrev videre at skolebyråkrater presset skoler til drilling av elever, og at $73 \%$ av lærerne følte seg presset til det $(V G, 15.1 .2013)$. Dagen etter slo samme avis opp under overskrifter om "full alarm» at lærerstudenter fikk sjokk over hvordan nasjonale prøver blir brukt i skolen: «skoleledelsen delte ut en nesten helt identisk nasional prøve til lærere to uker før den nasjonale prøven [... og vi ...] så hvordan lærere utnyttet muligheten til veiledning under selve prøven. De gikk langt i å hjelpe elevene fram til riktig svar. De anmodet eleven til å prøve igjen dersom svaret var feil», rapporterte lærerstudentene $(V G, 16.1 .2013)$. Også noen andre utviklingslinjer så ut til å begynne å avtegne seg blant skolepraktikerne. Sammen med innsnevringen av fokus som er beskrevet over, kom en innsnevring av forståelsen av utdanningskvalitet og skolens samfunnsmandat. I Adresseavisen brukte en rektor og en lærer hevdvunne formuleringer som «øvelse giør mester», men også nyvinninger som at man har valgt ut "smale satsingsområder», og at "Vi driver ikke unødvendig læring» (Adresseavisen, 28.1.2013). I noen grad og i enkelte sammenhenger kom en uenighet eller mangel på samstemthet mellom lærer og rektor til syne. Klassekampen brakte en artikkel om at de nasjonale prøvene var uegnet til å gi elevene tilbakemelding, og at de heller ikke kunne brukes til å si om en skole var god eller dårlig (Klassekampen, 24.4.2013). Her framsto rektorene som fornøyde med prøvene, mens lærerne ikke var det. Slike skiller fikk ny relevans da $V G$ publiserte artikler om hemmelige lederlønningskontrakter i Oslo-skolen (13. og 20.2.2013), og da det senere på våren ble en dominerende sak at Oslo-rektorer bekreftet at lønn ble påvirket av hvor godt elevene gjorde det på nasjonale prøver (Aftenposten, 8.5.2013).

Mot høsten 2013 tok Høyres kunnskapsminister Torbjørn Røe Isaksen til orde for å offentliggjøre også resultatene for den enkelte skole. Det han ønsket, var resultater som gav et bilde av hvilke skoler som løftet elevene mest, og han var opptatt av å få resultater som kunne vise utvikling over tid (Adresseavisen, 30.10.2013). I Aftenposten (30.10.2013) understreket Oslos nye skolebyråd Annikken Haugli $(\mathrm{H})$ det samme, at sammenligning mellom fylker var uinteressant, det var tendensene i Oslo over tid hun kunne bruke som styringsverktøy. Det samme blir understreket av en skolesjef i Stavanger Aftenblad: «-Vi bruker disse tallene veldig systematisk til elevenes læringsutvikling, og ikke som en konkurranse mellom skolene. Prøvene er likevel med på å gi oss et bilde om at vi har en utfordring på en skole, eller i en bydel» (31.10.2013). 
Også i 2014 var debatten om nasjonale prøver konsentrert om spørsmål om offentliggjøring. Tanken om å bruke prøvene mer som en skolebidragsindikator ble løftet fram: Hvilke skoler løfter elevene mest? (Dagsavisen, 20.1.2014) Aftenposten fortalte den 25.9.2014 at Oslo kommune hadde samlet resultatene av nasjonale og andre prøver på Minosloskole.no. Haugli understreket at dette ble gjort uten rangering: «Det er ikke meningsfullt og forteller ikke så mye om kvaliteten på undervisningen» (Aftenposten, 25.9.2014). Da tidspunktet for offentliggiøring av 2014-prøvene kom på høsten, var dette første gang at resultatene skulle offentliggiøres på skolenivå for alle på et nasjonalt nivå. Elevorganisasjonen fryktet at utviklingen ville føre til unaturlig segregering mellom skolene, og rykket ut i pressen med en bønn om at den var varsom i forbindelse med offentliggiøringen av resultatene på de nasjonale prøvene (Dagsavisen og Klassekampen, 2.12.2014). Rangering av enkelte skoler var likevel ikke langt unna. Aftenposten fortalte (3.12.2014) at «Nå kan alle sjekke sin skole». Slik ble det også enklere for skolene og skoleeierne å se utviklingen fra år til år, og kontrollere effekten av tiltak som måtte være satt inn, fortalte oppslaget. I Bergens Tidende (3.12.2014) gikk rektorer og lærere ut for å støtte opp under elevtesting. Elevorganisasjonen stilte seg "veldig positive» til nasjonale prøver som styringsverktøy, men negative til offentliggiøring av enkeltskolers resultater. Oppslag som dette er tydelige tegn på at holdningene til prøvene nå hadde blitt endret.

\section{Naturaliseringen fullføres 2015-2017}

På sommeren og høsten 2015 reiste det seg et foreldreopprør mot Oslo-skolen (Dagsavisen, 29.6.2015). Oslo brukte mest på skole, men hadde de minst fornøyde innbyggerne, kunne både Aftenposten og Adresseavisen melde (21.7.2015). Noe av kritikken bunnet i oppslag om at Oslo-skolen opererte med øveprøver og fasit før kartlegging. Avisene brakte intervjuer med lærere som sluttet på grunn av alle prøvene og testregimet, og fordi de var oppgitte over juks. Mange av påstandene som Marsdal fremmet i boka si, så dermed ut til å bli bekreftet. Rektorer avviste at praksisen var problematisk, og sa det var snakk om å øve på prøveformen ( $V G, 24.9 .2015)$. Likevel kom en jevn strøm av artikler om øving på kartleggingsprøvene (for eksempel Klassekampen, 29.9.2015). Utdanningsforbundet rapporterte om stadige meldinger fra lærere om pålegg om øving til slike prøver. Klassekampen brakte oppslag om Utdanningsdirektoratet og Lesesenteret ved Universitetet i Stavanger som pekte på mangler ved prøvepraksisen i Oslo-skolen: For det første var det mye som tydet på øving til prøvene. For det andre pekte de på at prøvene ble brukt feil: De var designet slik at $20 \%$ av barna skulle prestere under bekymringsgrensen, men likevel hadde flere skoler målsetting om at ingen elever skulle havne under grensen (1.10.2015). Denne kritikken var ikke den første fra disse fagmiljøene mot disse prøvene og bruken av dem. Likevel ser kritikken ut til å ha fått begrenset gjennomslag, i særdeleshet hos skolemyndighetene. Slik demonstrerer utviklingen også begrensningene i utvekslingen mellom medier, beslutningstakerne i politiske og administrative stillinger og fagfolk. Praksisen påvirkes ikke, og skolen blir løpende videre etter målsettinger som hele tiden flyttes fram. 
For øvrig preges oppslagene i 2016 av at de nasjonale prøvene på dette tidspunktet er tatt for gitt, og regnet som en selvskreven del av skolehverdagen, ute av sfæren for politiske vedtak. Medieomtalen avspeilet denne tankegangen og tjente samtidig til å befeste den gjennom å presentere denne bakgrunnen som gitt og fast for sine reportasjer. Et par typiske artikler kan illustrere denne tendensen. Nordlys brakte en artikkel om Tromsø-skolene som bar tittelen «Store forskjeller» (15.8.2016). En stor del av oppslaget er tallmateriale i form av tabeller over skoleresultater. Tabellene er i seg selv en form for påstand om å være rene fakta, og disse er dessuten innrammet av kommentarer som underbygger deres faktisitet. Den eneste modererende kommentaren er fra en skolefaglig rådgiver som peker på at tallgrunnlaget i enkelte tilfeller er lite på grunn av at skolene er små. De nasjonale prøvenes evne til å avspeile et faglig nivå eller en sannhet om skolen er ikke tematisert. Et annet og like typisk eksempel finnes i Aftenposten (2.12.2016). Overskriften og hovedbudskapet lyder: «Oslo og Bærum fortsatt best på nasjonale prøver». Overskriften og brødteksten refererer både eksplisitt og implisitt til tidligere tester som har vist at skolene i Oslo og Bærum har fått gode resultater på prøvene. Denne kontinuiteten ser ut til å bære i seg en bekreftelse i seg selv, og innenfor den interne logikken som denne spesielle artikkelsjangeren beherskes av, ser prøvene og resultatene ut til å bekrefte hverandres gyldighet. I alle fall blir det ikke i disse artiklene lenger stilt kvalifiserte spørsmål ved hva de nasjonale prøvene måler, eller hvilke kvalitetsbegrep eller hvilke elever som faller utenfor. De nasjonale prøvene er naturalisert, i den forstand at resultatene ses som sementerte og naturgitte. I VG (20.1.2017) viste skoler som gjorde det godt på undersøkelser, eksplisitt til nasjonale prøver som et viktig verktøy i seg selv. De nasjonale prøvene ble framhevet som en base og et fundament for styring. De nasjonale prøvene var ikke lenger stridens eple, de var ikke en gang ansett som en politisk sak. I stedet er de på dette tidspunktet forstått nærmest som naturgitte og deres resultater anerkjent som avpolitiserte og uproblematiserte fakta.

I 2017 ble den såkalte skolebidragsindikatoren publisert. Dette ble presentert som et verktøy basert på nasjonale prøver, men som i tillegg korrigerer for foreldres utdanningsnivå og sosioøkonomiske bakgrunn (Dagsavisen, 20.1.2017; VG, 20.1.2017). Røe Isaksen sa da at dette er et bedre verktøy enn de nasjonale prøvene, siden denne indikatoren viste hva skole og skoleeier faktisk bidro med. På denne måten uttrykkes en slags kritikk av de nasjonale prøvene. Samtidig underbygges det prosjektet disse nasjonale prøvene er en del av: et prøveregime og en tenkning der kvalitet ikke bare måles, men også offentliggjøres, og nå brutt helt ned på enkeltskoler. Med dette er skyldfordelingen entydig og endelig flyttet over på skolene, siden sosioøkonomisk bakgrunn for elevene er korrigert for og tatt ut av regnestykket. Samtidig ser det ut til at den nasjonale konkurransen etter hvert ikke lenger gikk ut på å gratulere seg selv, men i litt større grad fungerte som et incitament til selvrefleksjon. Kanskje ga det litt mer nyanserte og presise instrumentet en motivering til at skoleeiere og skoleledere kunne eller måtte nyansere og reflektere, snarere enn gå inn i en blind og rå rivalisering mellom naboer, slik som det stumpe våpenet nasjonale prøver kan ha pekt i retning av? 
Idet 2017 ebbet ut, kunne man også se et slags foreløpig endepunkt i diskusjonen om de nasjonale prøvene. I en lederartikkel omtalte Aftenposten en evaluering av 600 ekstra lærere i ungdomsskolen. Forskerne bak rapporten kunne ikke påvise noen tegn til effekt av å øke lærertettheten, og lederskribenten kommenterer:

\begin{abstract}
Det paradoksale, som også evalueringsrapporten behandler, er at både rektorer, lærere og elever har en annen opplevelse. Et flertall av de spurte rektorene mener lærerøkningen «i stor grad» har bidratt til å øke læringsutbyttet til elevene. Lærere opplever økt samarbeid og en mer overkommelig arbeidssituasjon. Elevene sier det er lettere å ta ordet og spørre i mindre grupper. Men dette gir seg altså ikke utslag hverken på avgangskarakteren eller nasjonale prøver. Opplevelser av forbedring er bra, men metodisk kan ikke slike måle seg med forskningen (Aftenposten, 13.12.2017, vår utheving).
\end{abstract}

Dette er vel den ytterste konsekvensen av måletenkingen i sin aller mest rendyrkede form. Entydige konklusjoner fra rektorer, lærere og elever blir avfeid som «opplevelser», mens de nasjonale prøvenes to streker under svaret representerer den endelige og gjeldende sannhet. Slik representerer Aftenpostens lederartikkelen et sluttpunkt på en utvikling som ble spådd allerede da de nasjonale prøvene ble lansert: en full innsnevring av debatten, av kvalitetsbegrepet, og av hva som er forskning eller sannhet.

\title{
Oppsummering
}

Framstillingen vi har gitt ovenfor av hvordan mediene har dekket utviklingen av de nasjonale prøvene, er forenklet. Utvalget vårt er avgrensende i utgangspunktet, og vi har skåret bort nyanser og avvik for å profilere hva vi ser som de viktigste hovedtendensene i utviklingen. Den kanskje viktigste mangelen ved en slik grovkornet framstilling med vekt på endringer og brudd, må framheves spesielt her. Mediedebatten om de nasjonale prøvene har en noe rituell karakter, der en kjede av hendelser følger på hverandre i et fast mønster hvert år, og skaper en velkjent dramaturgi:Ved begynnelsen av hver syklus bygges en spenning gjennom forventningsskapende artikler. Deretter blir resultatene av årets tester presentert gjennom artikler som tenderer til å vektlegge ulikheter mellom skoler, og gjerne den relative plasseringen av ens «egen» skole. Den siste fasen er hvor politikere, rektorer, og implisitt lærerne, blir konfrontert med resultatene. Gjennom hele perioden er et stadig tilbakevendende motiv i dekningen framvisning av aktører og deres resultater. I de tidlige årene er det fylker, kommuner, regioner som er aktørene, deretter blir det enkeltskoler. Disse artiklene, spredt over både nasjonale, regionale og ikke minst lokale aviser, er ofte bare smånotiser, ikke minst etter hvert som de nasjonale prøvene har fått noen år på baken. Disse smånotisenes størrelse og plassering avspeiler at nyhetens interesse har avtatt, og funnene er i seg selv heller ikke egnet til å overraske. Det som står igjen, er en liten rest av et komparativt, eller kompetitivt, element: Prøvene egner seg best til, eller innbyr i alle fall i størst grad til, å stille ulike grupper opp mot hverandre. At mediene giør dette, er ikke overraskende. For de profesjonelle aktørene i utdanningssektoren, 
ikke minst lærerne, er det annerledes, og det er en stadig og vedvarende kilde til irritasjon og frustrasjon, at det er gjennom slike sammenstillinger at prøvene framkommer og blir brukt i offentligheten. Like fullt er det disse stadige repetisjonene av det komparative, eller kompetitive, potensialet som former forståelsen av prøvene, som bestemmer deres verdi i politisk sammenheng, og som dermed bestemmer deres bruk. Journalistenes bidrag i debatten består i å bryte ned prøvene i grupper og sammenstille disse: mellom fylker, mellom kommuner, mellom kjønn og mellom skoler. Dermed tilfredsstilles journalistenes behov for å være gravende og kritiske, uten at prøvene blir gitt noen verdi eller funksjon gjennom dekningen. Men for leserne er denne vinklingen forførende, og man føler en viss grad av innsikt, og av at egne erfaringer med skoler blir satt inn $i$ en meningsfull kontekst av system og mønster.

Utviklingen i Osloskolen har fått en drivende funksjon i debatten om nasjonale prøver, trass $i$ at mange av Osloskolens utfordringer står langt ifra utfordringene til mange andre skoler landet over. Gitt den offensive holdningen til den politiske og administrative ledelsen i Oslo har også Osloskolens avantgardistiske rolle gjort at aviser andre steder $i$ landet har fulgt og dekket utviklingen der med en viss iver og konsistens over tid. Det er trolig at dette Oslo-fokuset har påvirket forståelsen av nasjonale prøver i allmennheten, så vel som at utviklingen har banet vei i praktisk politikkutforming.

Denne mediedynamikken gjør at skepsisen til offentliggiøring av resultatene på nasjonale prøver kan anses velbegrunnet. Myndighetene forsikret i utgangspunktet om at resultatene ikke skulle offentliggjøres på en skadelig måte, og da slik offentliggøøring allikevel ble gjennomført, understreket myndighetene at hensikten med prøvene var en annen. Da Røe Isaksen i 2017 oppsummerte historien med at spådommen om rangering og uthenging ikke har holdt stikk, var dette en videreføring av en tildekkingsstrategi. Myndighetene har sine ord i behold i den forstand at man fra offentlig side ikke har rangert eller hengt ut aktører. Dette arbeidet har man kunnet overlate til medieaktørene, da det ligger i medienes natur at redaksjonene ville forsøke å hente ut, analysere og offentliggjøre resultatene.

\section{Forfatteromtale}

Ole Petter Vestheim er førsteamanuensis i pedagogikkk ved Fakultet for lærerutdanning og kunst- og kulturfag ved Nord universitet. Han underviser i pedagogikk og elevkunnskap på grunnskolelærerutdanningen samt på studiet Nordic and International Perspectives on Teaching and Learning. Forskningen hans har vært rettet mot hvordan standardiserte tester, som nasjonale prøver, påvirker praksis i skolen.

Leiv Sem er førsteamanuensis ved Fakultet for lærerutdanning og kunst- og kulturfag ved Nord universitet. Han har undervist i norsk i grunnskole- og barnehagelærerutdanning siden 2012. Forskingsinteressene hans omfatter litteratur, kulturhistorie og diskursanalyse. 


\section{Nasjonale prøver i norske riks- og regionaviser - en historisk tekstanalyse}

\section{Litteratur}

Altheide, D. L. (2004). Media logic and political communication. Political Communication, 21(3), $293-296$.

Baroutsis, A., \& Lingard, B. (2017). Counting and comparing school performance: an analysis of media coverage of PISA in Australia, 2000-2014. Fournal of Education Policy, 32(4), 432-449. https://doi.org/10. 1080/02680939.2016.1252856

Berliner, D. (2011). Rational responses to high stakes testing: the case of curriculum narrowing and the harm that follows. Cambridge fournal of Education, 41(3), 287-302.

Blackmore, J., \& Thorp, S. (2003). Media/ting change: the print media's role in mediating education policy in period of radical reform in Victoria, Australia. Fournal of Education Policy, 18(6), 577-595. https://doi. org/10.1080/0268093032000145854

Elstad, E., (2009). Schools which are named, shamed and blamed by the media: school accountability in Norway. Educational Assessment Evaluation and Accountability, 21(2), 173-189. https://doi.org/10.1007/ s11092-009-9076-0

Elstad, E., \& Sivesind, K. (2010). OECD setter dagsorden. I E. Elstad, \& K. Sivesind (Red.), PISA - sannheten om skolen? Oslo: Universitetsforlaget.

Fairclough, N. (2003). Analysing discourse: textual analysis for social research. London: Routledge.

Fladmoe, A. (2013). Education in the News and in the Mind. Nordicom Review, 33(2), 99.

Hargreaves, A., \& Shirley, D. (2009). The fourth way: The inspiring future for educational change. California: Corwin Press.

Hopfenbeck, T. N. (2014). Testing times: Fra PISA til nasjonale prøver. Intensjoner, ansvar og anvendelse. I J. H. Stray, \& L. Wittek (Red.), Pedagogikk - en grunnbok (s. 401-419). Oslo: Cappelen Damm Akademisk.

Hovdenakk, S. S. (2014). Utdanningspolitikk, forskning og kunnskapsformer. Globale og nasjonale tilnærminger. Norsk Pedagogisk Tidsskrift, 98(6), 395-409.

Lingard, B., \& Rawolle, S. (2004). Mediatizing educational policy: the journalistic field, science policy, and crossfield effects. Fournal of Education Policy, 19(3), 361-380. https://doi.org/10.1080/0268093042000207665

Marsdal, M. E. (2011). Kunnskapsbløffen: skoler som jukser, barn som gruer seg. Oslo: Manifest.

Mockler, N. (2013). Reporting the "education revolution": MySchool.edu.au in the print media. Discourse: Studies in the Cultural Politics of Education, 34(1), 1-16. https://doi.org/10.1080/01596306.2012.698860

Mediebedriftenes Landsforening. (2018). Medietall 18/2. Lesertall for mediehus og magasiner. Opplagstall for mediehus. Hentet 28.9.2018 fra https://www.mediebedriftene.no/siteassets/dokumenter/tall-og-fakta/ medietall_presentasjoner/medietall_18_2_presentasjon_sp.pdf

Saraisky, N. G. (2016). Analyzing Public Discourse: Using Media Content Analysis to Understand the Policy Process. Current Issues in Comparative Education, 18(1), 26-41.

Sjøberg, S. (2014). PISA-syndromet. Hvordan norsk skolepolitikk bliver styrt av OECD. Nytt Norsk Tidsskrift, 31(1), 30-43.

Stack, M. (2006). Testing, Testing, Read All about It: Canadian Press Coverage of the PISA Results. Canadian Fournal of Education / Revue canadienne de education, 29(1), 49-69. https://doi.org/10.2307/20054146

Waldow, F., Takayama, K. \& Sung, Y.-K. (2014). Rethinking the pattern of external policy referencing: media discourses over the "Asian Tigers'" PISA success in Australia, Germany and South Korea. Comparative Education, 50(3), 302-321. https://doi.org/10.1080/03050068.2013.860704

\section{Avisartikler med dato og tilhørende overskrift}

\section{Adresseavisen}

5.12.2007 «Elevene i sør scorer bedre enn de i nord»

1.9.2007 «Nye prøver uten boikott»

22.6.2012 «Høyre offentliggjør skoleresultater på nett» og «-De forstår ikke konsekvensen av dette»

26.6.2012 «Motstand mot skoleportal»

28.1.2013 "Øvelse gjør mester på nasjonale tester»

30.10.2013 «Vil måle skolenes evne til å lære bort»

21.7.2015 «Oslofolk minst fornøyde med egen skole»

20.1.2017 «Måler skolene for å løfte de svakeste» 


\section{Ole Petter Vestheim og Leiv Sem}

\section{Aftenposten}

17.6.2004 «Clemet vil ikke rangere skolene»

11.5.2005 «Vil ikke rette nasjonale prøver»

4.6.2008 «Små kommuner stryker på skolen»

23.4.2006 "Kø med prøver i Oslo-skolen Tøft i 'Djupedal-fri sone’»

12.11.2008 «Kartlegging = toppkarakter»

13.11.2008 «Åpenhet ga skolegull til Oslo»

26.5.2011 «Lærerne tør ikke uttale seg offentlig»

5.5.2011 «Vil sparke flere lærere»

21.12.2011 «Oslo fritar flest fra prøver - Skyldes resultatpress, mener Magnus Marsdal»

10.2.2012 «Vil endre nasjonale prøver»

8.5.2013 «Lærere belønnes for gode testresultater» og «Ikke eget kriterium»

30.10.2013 «Oslo-elever tester best i landet» og «På norsktoppen - igjen»

25.9.2014 "Her kan du se hvilke skoler som er best"

3.12.2014 «Nå kan alle sjekke sin skole» og «-Har ikke noe å skjule»

21.7.2015 «Oslo bruker mest på skole, men har de minst fornøyde innbyggerne»

2.12.2016 «Oslo og Bærum fortsatt best på nasjonale prøver»

13.12.2017 «Et tungt argument mot økt lærertetthet»

\section{Bergens Tidende}

30.3.2004 «Vi er én nasjon på kunnskapsprøvefakta / nasjonale prøver»

7.12.2007 «Bergenshåpet Hop»

3.12.2014 «Rektorer og lærere støtter opp om elevtesting»

\section{Dagbladet}

24.6.2010 «Forskjellsskolen skole»

23.8.2011 «Avviser påstandene»

23.8.2011 "Høyre-skolen beskyldes for JUKS»

6.2.2012 «Rektorene slakter nasjonale prøver»

\section{Dagsavisen}

25.8.2005 «Lærer-nei til offentliggiøring»

3.4.2005 "Foreldreaksjon mot nasjonale prøver»

28.3.2006 «Vil stenge skoleporten til Clemet»

28.8.2007 «Nasjonale prøver tilbake i ny drakt»

14.11.2008 «Skoleprøver innbyr til juks og snarveier»

9.2.2010 «Maner til opprør mot dårlige skoler»

28.3.2011 «Slår alarm om svake skoler»

29.3.2011 «-Gir opp de svake»

30.3.2011 «90 prosent skal fullføre videregående»

24.5.2011 "Læreropprør mot prøvepress»

20.1.2014 "Skal avdekke skolekvaliteten i Oslo»

2.12.2014 "Ber pressen være varsom»

29.6.2015 «Oppgjørets time er kommet»

20.1.2017 «Faktakampen om skolen»

11.7.2017 «Ingen omkamp om nasjonale prøver»

\section{Klassekampen}

24.5.2011 «Læreropprør mot prøvepress»

24.4.2013 «Elevene får lite igjen» 
2.12.2014 «Elevene ber pressen være varsom i år»

29.9.2015 «Øver på kartleggingsprøver»

1.10.2015 «Prøvene brukes feil i Oslo»

\section{Nordlys}

15.8.2016 «Store forskjeller»

\section{Stavanger Aftenblad}

31.1.2005 «Boikottet nasjonale prøver: Elevrådsmedlem truet med utkastelse»

20.12.2007 «Slik ble Smeaheia testvinner»

13.11.2008 «NASJONALE PRØVER Foreldrenes bakgrunn bestemmer mest»

9.4.2008 «Kommunen offentliggjør skolenes resultater på nettet»

31.10.2013 «De fleste er middels»

$V G$

18.1.2005 «Driller elevene før nasjonale prøver»

4.5.2011 «Vil tvangsinnføre tøffere skole. Erna varsler nye krav»

15.1.2013 «Svake elever holdes vekk for å blåse opp resultatene»

20.2.2013 «Stryker resultat-kontrakter»

24.9.2015 «Forsvarer øveprøvene» og "Derfor sluttet vi som lærere i Oslo-skolen»

20.1.2017 «Toppskår for å løfte lavskår» 